\title{
ANALISIS FAKTOR-FAKTOR YANG MEMENGARUHI EKSPLOITASI PEKERJA ANAK DI INDONESIA MENGGUNAKAN REGRESI LOGISTIK BINER*
}

\author{
Lissa Octavia Wardana ${ }^{1}$ and Liza Kurnia Sari² \\ ${ }^{1}$ Politeknik Statistika STIS, Indonesia, lissaoctavia05@gmail.com \\ ${ }^{2}$ Politeknik Statistika STIS, Indonesia, lizakurnia@stis.ac.id \\ Fcorresponding author
}
Indonesian Journal of Statistics and Its Applications (elSSN:2599-0802)
Vol 4 No 3 (2020), 432 - 447

Copyright (@ 2020 Lissa Octavia Wardana and Liza Kurnia Sari. This is an open-access article distributed under the Creative Commons Attribution License, which permits unrestricted use, distribution, and reproduction in any medium, provided the original work is properly cited.

\begin{abstract}
Every child has human rights to grow and develop as a whole, both physically and mentally. The government prohibits employers from employing children to protect children's rights. In reality, children begin to participate in economic activities as workers. The issue of child labor is very close to exploitation. This research aims to find general facts about exploitation on child laborers and to identify variables that influence exploitation on child laborers in Indonesia in 2018. Data of National Social and Economic Survey (Susenas) in 2018 were analyed through binary logistic regression. The result shows that most of child laborers in 2018 are exploited. Provinces with the highest percentage of child laborers exploitation are DKI Jakarta, Banten, and Central Java. Area of residence, child labor sector, gender of child, and education of household head in the category of junior high school, elementary school, or not graduate from school significantly influence the exploitation of child labor. Child laborers who live in urban areas, male, work in the formal sector, and has a household head who graduate from junior high school or elementary school or doesn't graduate at all are more likely experience exploitation.
\end{abstract}

Keywords: binary logistic regression, child, child labor, exploitation.

\footnotetext{
${ }^{*}$ Received Jan 2020; Accepted Oct 2020; Published online on Nov 2020
} 


\section{Pendahuluan}

Anak sebagai makhluk Tuhan Yang Maha Esa memiliki hak asasi atau hak dasar sejak dilahirkan, yakni jaminan untuk tumbuh dan berkembang secara utuh baik secara fisik maupun mental. Negara wajib untuk mengakui, menghormati, dan menghargai hak setiap warga negara sesuai dengan ketentuan Undang-Undang Dasar tahun 1945 pasal 28I yang menyatakan bahwa pelindungan, pemajuan, penegakan, dan pemenuhan hak asasi manusia adalah tanggung jawab negara, terutama pemerintah. Upaya perlindungan terhadap hak asasi manusia terutama bagi anak-anak dilakukan agar tidak terjadi perampasan hak-hak anak oleh pihak lain. Berdasarkan UndangUndang nomor 23 tahun 2002 pasal 1 ayat 2, perlindungan anak adalah segala kegiatan untuk menjamin dan melindungi anak dan hak-haknya agar dapat hidup, tumbuh, berkembang dan berpartisipasi secara optimal sesuai dengan harkat dan martabat kemanusiaan, serta mendapat perlindungan dari kekerasan dan diskriminasi.

Dalam Undang-Undang nomor 23 tahun 2002 pasal 11 disebutkan seorang anak berhak untuk beristirahat dan memanfaatkan waktu luang, bergaul dengan anak yang sebaya, bermain, dan berkreasi, sehingga seharusnya tidak boleh bekerja karena waktu yang mereka miliki selayaknya dimanfaatkan untuk menikmati masa-masa kecil yang tidak akan terulang kembali. Undang-Undang nomor 13 tahun 2003 pasal 68 dengan tegas menyebutkan bahwa pengusaha dilarang untuk mempekerjakan anak. Larangan tersebut dikeluarkan untuk melindungi hak-hak seorang anak agar ia tidak mengalami gangguan perkembangan kesehatan fisik, mental, dan sosial. Namun, anak-anak mulai ikut serta terlibat secara aktif dalam kegiatan ekonomi sebagai seorang pekerja karena tekanan kemiskinan yang dialami oleh rumah tangga (Akarro \& Mtweve, 2011). Oleh karena itu, keberadaan pekerja anak di Indonesia perlu diawasi agar hak-hak anak tetap terlindungi.

Pemerintah Republik Indonesia melalui Kementerian Ketenagakerjaan menyusun Peta Jalan (Roadmap) Menuju Indonesia Bebas Pekerja Anak tahun 2022. Peta jalan tersebut disusun untuk melakukan percepatan dalam penghapusan pekerja anak secara efektif dan efisien sampai tahun 2022 (KEMNAKER, 2014). Pada Survei Pekerja Anak (SPA) tahun 2009 tercatat bahwa di Indonesia terdapat 2,89 persen atau sekitar 1,7 juta jiwa anak yang menjadi pekerja anak dalam rentang usia 5 sampai 17 tahun (BPS, 2010). Selain itu, berdasarkan olahan data Susenas tahun 2015 sampai 2018 dapat diketahui bahwa jumlah pekerja anak di Indonesia mengalami penurunan dari tahun 2015 hingga tahun 2018. Pada tahun 2015, jumlah pekerja anak di Indonesia diperkirakan jumlahnya sebanyak 1,068 juta orang. Jumlah pekerja anak di Indonesia kembali mengalami penurunan di tahun-tahun berikutnya, hingga pada tahun 2018 mencapai 853 ribu orang. Masih banyaknya pekerja anak di Indonesia menunjukkan bahwa tujuan dari Peta Jalan (Roadmap) Menuju Indonesia Bebas Pekerja Anak tahun 2022 belum sepenuhnya dapat tercapai.

Pada kenyataannya, isu pekerja anak bukan hanya sekedar anak-anak yang melakukan pekerjaan dalam kurun waktu tertentu untuk memperoleh upah. Namun, pekerja anak sangat lekat dengan eksploitasi, pekerjaan berbahaya, terhambatnya akses pendidikan serta menghambat perkembangan fisik, psikis, dan sosial anak (Joni \& Tanamas, 1999). Tuntutan untuk memenuhi kebutuhan hidup dijadikan sebuah alasan untuk mempekerjakan anak-anak, bahkan dengan pekerjaan yang eksploitatif, upah murah, dan pekerjaan yang berbahaya (Iryani \& Priyarsono, 2013). Adanya 
dorongan dari masyarakat yang beranggapan bahwa anak-anak merupakan pribadi yang lemah membuat anak-anak semakin rawan untuk dijadikan objek eksploitasi.

Eksploitasi pekerja anak merujuk pada perlakuan sewenang-wenang terhadap anak. Anak dipaksa untuk melakukan sesuatu demi memenuhi kepentingan ekonomi, sosial, maupun politik tanpa memperhatikan hak-hak anak untuk mendapatkan perlindungan (Suharto, 2005 dalam (Iryani \& Priyarsono, 2013)). Secara tidak langsung, eksploitasi pekerja anak akan memengaruhi kualitas hidup anak di masa depannya. Hal ini disebabkan karena seorang pekerja anak yang menjadi korban eksploitasi cenderung memiliki keterbatasan dari segi waktu maupun kesempatan untuk mengembangkan potensi yang dimilikinya.

Dampak yang ditimbulkan dari eksploitasi pekerja anak dapat berupa gangguan pada anak, baik secara fisik maupun mental, seperti rentan mengalami kecelakaan kerja dan merasa rendah diri dalam pergaulan sehingga tidak mampu bersaing dengan pihak lain dalam era globalisasi (Sulastri, 2016). Sebagai upaya untuk menekan kasus eksploitasi pekerja anak, pemerintah mengeluarkan peraturan tentang perlindungan khusus kepada anak yang dieksploitasi secara ekonomi dan/atau seksual dalam Undang-Undang nomor 35 tahun 2014 pasal 59 ayat 2. Namun, pada kenyataannya kasus ekploitasi pekerja anak di Indonesia masih saja terjadi.

Berdasarkan data Komisi Perlindungan Anak Indonesia (KPAl), dari keseluruhan kasus perlindungan anak di Indonesia tahun 2015, sebesar 29,1 persen di antaranya merupakan kasus eksploitasi pekerja anak (KPAl, 2016). Selain itu, hasil olahan data Susenas tahun 2015 sampai 2018 menunjukkan bahwa besarnya persentase pekerja anak sebagai korban eksploitasi setiap tahunnya mengalami fluktuasi. Pada tahun 2015, sebesar 82,11 persen dari pekerja anak mengalami eksploitasi. Pada tahun 2016, persentase pekerja anak yang tereksploitasi turun menjadi 75,89 persen. Namun, penurunan persentase pekerja anak yang tereksploitasi tersebut tidak berlanjut pada tahun-tahun setelahnya bahkan justru mengalami kenaikan. Pada tahun 2017 tercatat bahwa 86 persen dari pekerja anak mengalami eksploitasi. Kemudian, persentase eksploitasi pekerja anak kembali mengalami kenaikan menjadi 87 persen pada tahun 2018.

Berdasarkan uraian di atas, dapat diketahui bahwa persentase pekerja anak di Indonesia dari tahun ke tahun sudah mengalami penurunan. Namun, penurunan jumlah pekerja anak tidak diikuti oleh penurunan besarnya persentase pekerja anak yang mengalami eksploitasi. Oleh karena itu, penelitian ini ingin mendapatkan gambaran umum dan mengidentifikasi variabel-variabel yang memengaruhi eksploitasi pekerja anak di Indonesia tahun 2018 dalam upaya menemukan solusi terbaik untuk mengatasi masalah eksploitasi pekerja anak.

Silitonga (2009) melakukan sebuah penelitian untuk mengetahui faktor-faktor yang memengaruhi terjadinya eksploitasi pekerja anak di Indonesia. Jenis kelamin Kepala Rumah Tangga (KRT), pendidikan KRT, tempat tinggal KRT, status aktivitas kegiatan ekonomi KRT, status pekerjaan KRT, kemiskinan, jenis kelamin anak, dan jumlah anak dalam rumah tangga diprediksi sebagai variabel-variabel yang memengaruhi terjadinya eksploitasi pekerja anak di Indonesia. Kriteria terjadinya eksploitasi yang digunakan dalam penelitian ini adalah apabila seorang anak memiliki jam kerja lebih dari sama dengan 20 jam per minggu, mengalami putus sekolah, dan mendapatkan upah di bawah upah minimum regional/upah minimum provinsi. Hasil penelitian 
dengan menggunakan regresi logistik biner menunjukkan bahwa kemiskinan kepala rumah tangga mempengaruhi risiko terjadi eksploitasi pekerja anak, semakin miskin kepala rumah tangga maka akan semakin tinggi risiko pekerja anak tereksploitasi. Selain itu, pekerja anak laki-laki lebih berisiko untuk tereksploitasi dibandingkan dengan pekerja anak perempuan. Variabel lain yang terbukti berpengaruh pada eksploitasi pekerja anak yakni sektor lapangan pekerjaan anak, tempat tinggal KRT, pendidikan KRT, sektor pekerjaan KRT, kegiatan ekonomi KRT, dan jumlah anak dalam keluarga (Silitonga, 2009).

Penelitian yang dilakukan oleh Iryani \& Priyarsono (2013) bertujuan untuk mengetahui tingkat keparahan eksploitasi terhadap anak yang bekerja dan faktorfaktor yang memengaruhi terjadinya eksploitasi. Tingkat keparahan eksploitasi diperoleh dari penyusunan sebuah indeks yang digunakan untuk melihat peringkat keparahan eksploitasi setiap provinsi di Indonesia. Sumber data pada penelitian ini adalah Sakernas tahun 2011 yang kemudian dianalisis menggunakan Regresi Logistik. Variabel-variabel yang digunakan dalam penelitian ini antara lain daerah tempat tinggal anak, jenis kelamin anak, lapangan usaha anak, pendidikan KRT, status kedudukan anak dalam pekerjaan, dan jam kerja anak. Berdasarkan tingkat keparahan eksploitasi, terdapat tiga provinsi yang selalu tinggi nilai keparahan eksploitasinya, yaitu DKI Jakarta, Banten, dan Jawa Tengah. Pendidikan KRT merupakan salah satu faktor yang berpengaruh terhadap eksploitasi dari segi jam kerja dan akses pendidikan. Semakin rendah pendidikan KRT, semakin besar peluang anak untuk tereksploitasi. Sedangkan untuk eksploitasi dari segi upah, anak perempuan memiliki peluang 2,36 kali untuk tereksploitasi dari segi upah dibandingkan anak laki-laki. (Iryani \& Priyarsono, 2013)

Pada tahun 2016, Dewi Sulastri melakukan penelitian mengenai faktor-faktor penyebab eksploitasi pekerja anak pada tambang emas tradisional di Desa Kelian Dalam, Kecamatan Tering, Kabupaten Kutai Barat. Metode analisis data kualitatif model analisis interaktif dipilih untuk meneliti faktor-faktor yang menyebabkan eksploitasi pekerja anak pada tambang emas tradisional di Desa Kelian Dalam, Kecamatan Tering, Kabupaten Kutai Barat. Beberapa faktor yang melatarbelakangi eksploitasi pekerja anak yaitu ekonomi keluarga yang rendah, pengaruh lingkungan, fasilitas pendidikan yang belum memadai serta adanya motivasi dan budaya masyarakat setempat. Selain itu, peran keluarga dan kepala desa yang secara fungsional belum maksimal dalam menjalankan tugasnya sebagai pemimpin juga menjadi salah satu faktor yang mengakibatkan terjadinya eksploitasi pekerja anak (Sulastri, 2016).

\section{Metodologi}

\subsection{Bahan dan Data}

Data yang digunakan dalam penelitian ini merupakan data sekunder berupa data mentah (raw data) dari Survei Sosial Ekonomi Nasional (Susenas) Kor Maret tahun 2018. Unit analisis yang diteliti adalah pekerja anak di Indonesia. Pekerja anak yang memiliki status sebagai kepala rumah tangga tidak tercakup dalam penelitian ini untuk mencegah terjadinya tumpang tindih dengan karakteristik kepala rumah tangga. Berdasarkan data Susenas Maret 2018, terdapat 4.733 orang pekerja anak dan 
sebanyak 3.758 orang di antaranya merupakan pekerja anak yang mengalami eksploitasi. Kriteria pekerja anak dalam penelitian ini menggunakan konsep BPS dengan batasan umur disesuaikan dengan ketersediaan informasi yang dicakup dalam Susenas Kor Maret 2018. Pekerja anak adalah (1) anak berumur 10-12 tahun yang bekerja tanpa minimal jam kerja, (2) anak berumur 13-14 tahun yang bekerja lebih dari 15 jam per minggu, dan (3) anak berumur 15-17 tahun yang bekerja lebih dari 40 jam per minggu. Sementara itu, status eksploitasi pekerja anak ditinjau dari dua sisi, yaitu pendidikan dan jumlah jam kerja. Seorang pekerja anak mengalami eksploitasi dari sisi pendidikan apabila terhambat kesempatannya untuk memperoleh pendidikan yang dapat ditinjau dari status partisipasi sekolahnya, yaitu tidak/belum sekolah atau tidak bersekolah lagi. Seorang pekerja anak mengalami eksploitasi dari sisi jam kerja apabila selama seminggu bekerja lebih dari 20 jam. Apabila seorang pekerja anak sudah memenuhi salah satu kriteria eksploitasi, baik dari sisi pendidikan maupun jumlah jam kerja maka sudah dapat dikategorikan sebagai pekerja anak yang tereksploitasi.

Variabel dalam penelitian ini terbagi menjadi dua jenis, yaitu variabel respon (dependen) dan variabel penjelas (independen). Variabel respon yang digunakan adalah status ekploitasi pekerja anak yang dibagi menjadi 2 kategori, yaitu pekerja anak yang tereksploitasi dan pekerja anak yang tidak tereksploitasi. Terdapat 6 variabel penjelas yang digunakan yakni klasifikasi wilayah tempat tinggal, status kemiskinan, jenis kelamin anak, sektor pekerjaan anak, status pekerjaan KRT, dan pendidikan KRT.

\subsection{Metode Penelitian}

Metode analisis yang digunakan untuk menjawab tujuan penelitian adalah analisis deskriptif dan analisis inferensia. Analisis deskriptif memberikan gambaran umum eksploitasi pekerja anak di Indonesia pada tahun 2018 yang disajikan melalui tabel dan diagram. Selain itu, dilakukan analisis inferensia dengan regresi logistik biner untuk mengidentifikasi variabel-variabel yang memengaruhi eksploitasi pekerja anak dan besarnya rasio kecenderungan dari setiap variabel yang memengaruhi eksploitasi pekerja anak. Dalam penelitian ini, analisis deskriptif digunakan untuk menyajikan gambaran umum eksploitasi pekerja anak di Indonesia pada tahun 2018. Selain itu, dilakukan analisis inferensia dengan regresi logistik biner untuk mengidentifikasi variabel-variabel yang memengaruhi eksploitasi pekerja anak di Indonesia tahun 2018 dan besarnya rasio kecenderungan dari setiap variabel yang memengaruhi eksploitasi pekerja anak di Indonesia tahun 2018.

Analisis regresi digunakan untuk melihat hubungan antara variabel respon dan variabel penjelas. Pada analisis regresi logistik, variabel respon yang dianalisis berupa data kualitatif dengan skala pengukuran nominal atau ordinal, sementara variabel penjelas dapat berupa data kualitatif yang berskala pengukuran nominal atau ordinal maupun data kuantitatif yang berskala pengukuran interval atau rasio. Apabila variabel respon penelitian berupa data kategorik berskala nominal yang terdiri dari 2 kategori (data dikotomik atau biner), maka untuk melakukan pendugaan parameter dapat menggunakan analisis regresi logistik biner (Agresti, 2007).

Kategori dalam variabel dikotomik adalah yaitu kategori yang menyatakan kejadian gagal $(Y=0)$ dan kejadian sukses $(Y=1)$ dengan asumsi variabel respon berdistribusi 
Bernoulli. Dugaan dari hubungan variabel respon $(Y)$ dan variabel penjelas $(X)$ dinyatakan dengan $E(Y \mid x)$ yang memiliki peluang antara 0 sampai 1. Nilai $E(Y \mid x)$ dapat ditulis sebagai $\pi(x)$ yang menyatakan peluang terjadinya kejadian sukses, yaitu pada saat $Y=1$. Nilai $\pi(x)$ harus lebih besar atau sama dengan 0 dan kurang dari atau sama dengan $1,0 \leq \pi(x) \leq 1$. Bentuk umum model regresi logistik biner yang dipengaruhi $p$ variabel penjelas diformulasikan sebagai berikut.

$$
\pi(x)=\frac{\exp \left(\beta_{0}+\beta_{1} x_{1}+\cdots+\beta_{p} x_{p}\right)}{1+\exp \left(\beta_{0}+\beta_{1} x_{1}+\cdots+\beta_{p} x_{p}\right)}
$$

Keterangan:

$$
\begin{aligned}
\pi(x) & =\text { peluang kejadian sukses } \\
\beta_{j} & =\text { nilai parameter ke- } j \text { dengan } j=1,2, \ldots, p \\
x_{j} & =\text { variabel penjelas ke- } j \text { dengan } \mathrm{j}=1,2, \ldots, p \\
\mathrm{p} & =\text { banyaknya parameter }
\end{aligned}
$$

Fungsi $\pi(x)$ merupakan fungsi non linier sehingga perlu dilakukan transformasi ke dalam bentuk logit untuk memperoleh fungsi yang linier. Persamaan yang didapatkan setelah melakukan transformasi logit $\pi(x)$ sebagai berikut.

$$
\begin{aligned}
g(x) & =\ln \frac{\pi(x)}{1-\pi(x)} \\
& =\beta_{0}+\beta_{1} x_{1}+\cdots+\beta_{p} x_{p}
\end{aligned}
$$

Keterangan: fungsi $g(x)$ adalah fungsi yang linier dalam parameter.

Variabel penjelas yang berskala nominal dengan $k$ kategori memerlukan sebanyak $k-1$ variabel boneka. Sebagai contoh, variabel penjelas ke-j memiliki $k_{j}$ kategori, maka variabel boneka $\mathrm{k}_{\mathrm{j}}-1$ dinotasikan $D_{j 1}$ dengan koefisien $\beta_{j 1}$, untuk $j=1,2, \ldots, k-1$. Dengan demikian, model logit dengan $p$ variabel penjelas dan variabel penjelas ke- $j$ yang mempunyai $k_{j}$ kategori diformulasikan sebagai berikut.

$$
g(x)=\beta_{0}+\beta_{1} x_{1}+\cdots+\sum_{j=1}^{k-1} \beta_{j 1} D_{j 1}+\cdots+\beta_{p} x_{p}
$$

Dalam regresi logistik, variabel respon diformulasikan sebagai berikut.

$$
y=\pi(x)+\varepsilon
$$

Nilai error $(\varepsilon)$ memiliki dua kemungkinan nilai yaitu: jika $\mathrm{y}=1$, maka $\varepsilon=1-\pi(x)$ dengan peluang sebesar $\pi(x)$ dan jika $\mathrm{y}=0$, maka $\varepsilon=-\pi(x)$ dengan peluang sebesar $1-\pi(x)$ . Oleh karena itu, error $(\varepsilon)$ berdistribusi binomial dengan rata-rata $\pi(x)$ dan varians $\{\pi(x)[1-\pi(x)]\}$ (Hosmer et al., 2013).

Metode yang digunakan untuk menduga parameter adalah maximum likelihood estimation (MLE). Metode ini menghasilkan nilai parameter dengan memaksimalkan peluang dari data yang diamati dengan menggunakan fungsi likelihood. Fungsi ini menyatakan peluang dari data yang diamati sebagai fungsi dari parameter yang tidak diketahui.

$$
l(\boldsymbol{\beta})=\prod_{i=1}^{n}\left[\pi\left(x_{i}\right)\right]^{y_{i}}\left[1-\pi\left(x_{i}\right)\right]^{1-y_{i}}
$$

Nilai estimasi $\beta$ didapatkan dengan memaksimumkan fungsi likelihood dari persamaan (5). Secara matematis, akan lebih mudah jika menggunakan logaritma 
natural dari persamaan (5) sehingga diperoleh

$$
\begin{aligned}
L(\boldsymbol{\beta}) & =\ln (l(\boldsymbol{\beta})) \\
& =\sum_{i=1}^{n}\left[y_{i} \ln \left(\pi\left(x_{i}\right)\right)+\left(1-y_{i}\right) \ln \left(1-\pi\left(x_{i}\right)\right)\right] \\
& =\sum_{j=0}^{p}\left(\sum_{i=1}^{n} y_{i} x_{i j}\right) \beta_{j}-\sum_{i=1}^{n} \ln \left(1+\exp \sum_{j=0}^{p n} \beta_{j} x_{i j}\right)
\end{aligned}
$$

Tahapan analisis dalam regresi logistik biner sebagai berikut:

1. Melakukan estimasi parameter dalam model. Estimasi parameter diperoleh dengan memaksimumkan persamaan (6) yaitu mendiferensialkan $L(\boldsymbol{\beta})$ terhadap $\beta_{j}$ dan membuat hasil dari persamaan tersebut sama dengan nol.

2. Menguji signifikansi parameter secara simultan menggunakan uji Likelihood Ratio dengan statistik uji $G=-2 \ln \frac{l_{0}}{l_{1}} \sim \chi^{2}(p)$.

3. Menguji signifikansi parameter secara parsial menggunakan uji Wald dengan statistik uji $W_{j}=\frac{\hat{\beta}_{j}}{\operatorname{se}\left(\hat{\beta}_{j}\right)} \sim N_{(0,1)}$.

4. Menguji ketepatan atau kesesuaian model menggunakan uji Hosmer Lemeshow dengan statistik uji $\hat{C}=\sum_{k=1}^{g}\left[\frac{\left(o_{k}-n_{k}^{\prime} \bar{\pi}_{k}\right)^{2}}{n_{k}{ }_{k} \bar{\pi}_{k}\left(1-\bar{\pi}_{k}\right)}\right] \sim \chi^{2}{ }_{(g-2)}$. Hipotesis nol tidak ditolak menunjukkan model fit atau tidak terdapat perbedaan antara hasil observasi dan hasil prediksi dari model.

5. Melakukan penghitungan dan interpretasi rasio kecenderungan (odds ratio). Interpretasi rasio kecenderungan dilakukan dengan memperbandingkan kecenderungan terjadinya setiap kategori yang digunakan terhadap reference category.

\section{Hasil dan Pembahasan}

\subsection{Analisis Deskriptif}

Berdasarkan hasil pengolahan data Susenas Kor Maret 2018 ditemukan sebesar 4,4 persen dari anak-anak berumur 10 sampai 17 tahun merupakan anak yang bekerja. Keterlibatan anak pada rentang umur tersebut untuk bekerja menyalahi hasil ratifikasi Konvensi ILO nomor 138. Pada hasil ratifikasi tersebut dijelaskan bahwa pemerintah menetapkan batas minimum usia seorang anak untuk pekerjaan-pekerjaan yang membahayakan kesehatan, keselamatan, atau moral anak harus diupayakan tidak boleh kurang dari 18 tahun, kecuali untuk pekerjaan ringan tidak boleh kurang dari 16 tahun. Di sisi lain, terdapat anggapan bekerjanya seorang anak semata-mata hanya dianggap sebagai latihan. Anak yang ikut serta bekerja dalam sebuah rumah tangga akan mendapatkan wadah untuk berlatih mengembangkan keahlian dan keterampilan yang ia miliki sesuai dengan minatnya. Hal tersebut dapat dicapai selama anak bekerja dengan jam kerja sangat pendek, aktivitas pekerjaan tidak membahayakan bagi 
kesehatan, mendapatkan pengawasan dari orang yang lebih dewasa atau ahlinya, dan tidak dilakukan setiap hari sehingga anak masih dapat melakukan aktivitas rutinnya seperti sekolah, bermain, dan beristirahat (ILO, 2004).

Di antara anak yang bekerja di Indonesia, sebesar 51 persen di antaranya termasuk sebagai pekerja anak. Pekerja anak melakukan pekerjaan tertentu sebagai aktivitas rutin harian dengan jam kerja yang relatif panjang. Hal tersebut menyebabkan pekerja anak tidak dapat bersekolah serta tidak memiliki waktu yang cukup untuk bermain dan beristirahat seperti anak pada umumnya. Secara tidak langsung aktivitas yang dimiliki pekerja anak tersebut dapat berdampak buruk bagi kesehatan anak. Oleh karena itu, keadaan pekerja anak ini menjadi dilematis. Pada satu sisi, mereka dapat memberikan konstribusi pada pendapatan keluarga namun di sisi lain mereka rentan menjadi pekerja anak yang mengalami eksploitasi dan perlakuan salah (ILO, 2004).

Mayoritas dari pekerja anak di Indonesia tereksploitasi yaitu sebesar 81 persen. Hal tersebut menunjukkan bahwa dalam praktiknya pekerja anak cukup berisiko untuk menjadi korban eksploitasi. Rata-rata jumlah jam kerja seorang pekerja anak di Indonesia selama 40 jam per minggu yang menunjukkan bahwa rata-rata seorang pekerja anak di Indonesia memiliki jumlah jam kerja seperti jumlah jam kerja normal bagi seorang pekerja dewasa.

Persentase eksploitasi pekerja anak di setiap provinsi di Indonesia tahun 2018 ditampilkan pada Gambar 1. Pada tahun 2018, provinsi dengan persentase pekerja anak yang mengalami eksploitasi tertinggi terdapat di Pulau Jawa, yaitu di Provinsi DKI Jakarta, Banten, dan Jawa Tengah. Hasil tersebut tidak jauh berbeda dengan pernyataan Iryani \& Priyarsono (2013) yang menyatakan bahwa apabila dilihat dari tingkat keparahan eksploitasi dari sisi jam kerja, Provinsi DKI Jakarta, Banten, dan Jawa Tengah selalu menempati peringkat teratas. Salah satu penyebab tingkat keparahan eksploitasi tertinggi terjadi di DKI Jakarta adalah seluruh wilayah DKI Jakarta merupakan daerah perkotaan yang sangat kompleks akibat dari perannya sebagai pusat perekonomian Indonesia. Oleh karena itu, di DKI Jakarta tersedia banyak lapangan pekerjaan sehingga menyebabkan potensi eksploitasi yang besar bagi pekerja anak (Iryani \& Priyarsono, 2013).

Hasil eksplorasi data menunjukkan bahwa pekerja anak di Provinsi DKI Jakarta memiliki rata-rata jumlah jam kerja tertinggi di Indonesia, yaitu selama 55 jam per minggu. Jumlah jam kerja selama seminggu tersebut sudah melebihi batas minimal seorang pekerja anak untuk dikategorikan tereksploitasi. Selain itu, sebesar 64 persen di antara pekerja anak yang tinggal di DKI Jakarta berstatus tidak/belum bersekolah atau putus sekolah (tidak bersekolah lagi). Oleh karena itu, tidak mengherankan bahwa persentase eksploitasi pekerja anak di provinsi DKI Jakarta menempati peringkat pertama dibandingkan provinsi-provinsi lain di Indonesia. 


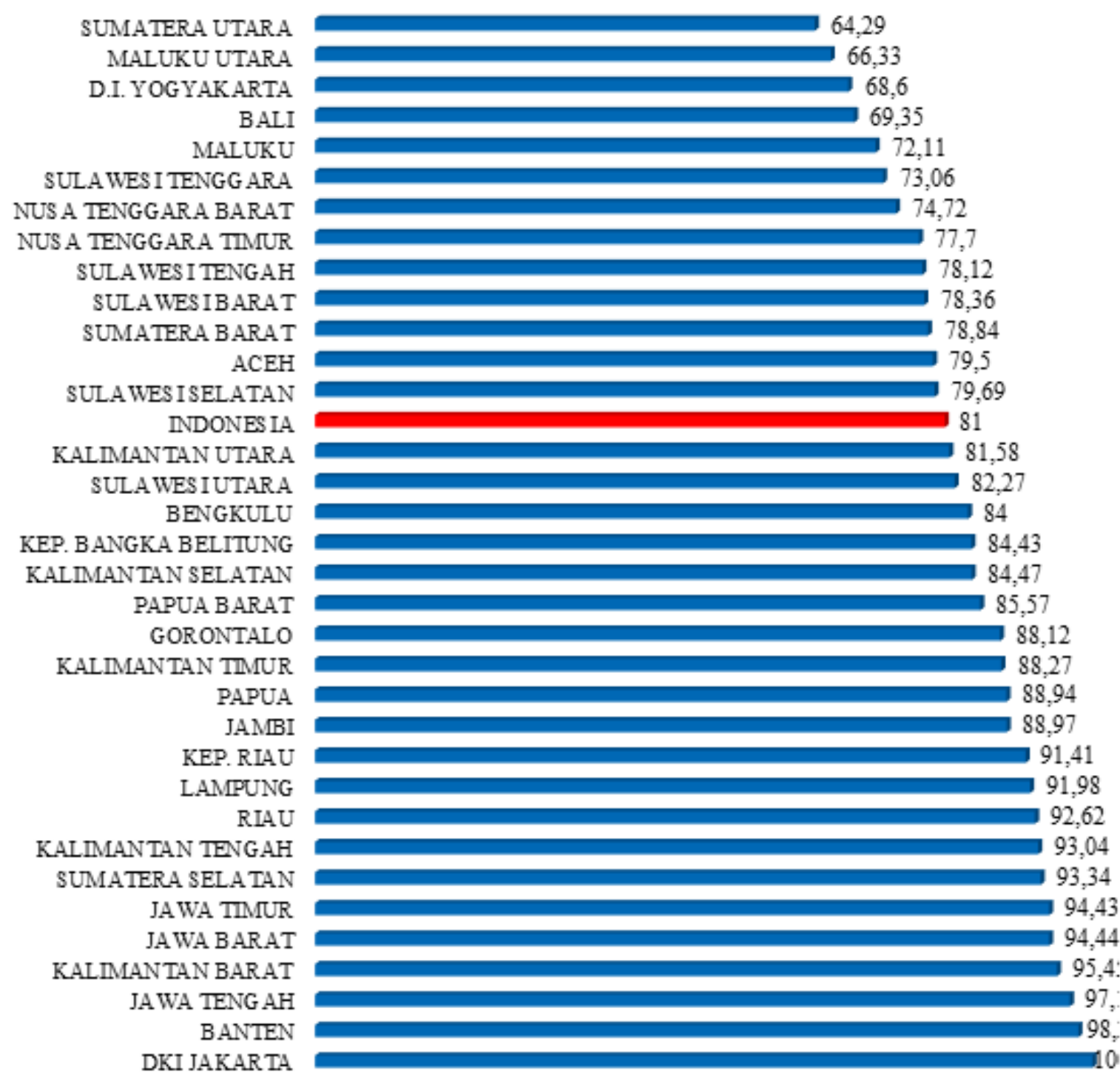

Sumber: Susenas 2018, diolah.

Gambar 1: Persentase eksploitasi pekerja anak di setiap provinsi tahun 2018.

Tabel 1 menunjukkan proporsi persentase eksploitasi pekerja anak di Indonesia tahun 2018 berdasarkan kategori pada variabel penjelas. Berdasarkan Tabel 1, sebesar 91 persen dari pekerja anak yang tinggal di perkotaan mengalami eksploitasi dan sebesar 84 persen dari pekerja anak yang ada di pedesaan mengalami eksploitasi. Oleh karena proporsi pekerja anak yang tereksploitasi di perkotaan lebih besar dibandingkan di pedesaan, hal ini menandakan bahwa pekerja anak yang tinggal di perkotaan lebih beresiko untuk mengalami eksploitasi.

Apabila ditinjau dari variabel status kemiskinan, sebesar 86 persen dari pekerja anak yang berasal dari rumah tangga miskin mengalami eksploitasi. Hal tersebut sejalan dengan pernyataan Fithriani (2011) bahwa anak yang hidup dalam kemiskinan pada umumnya menanggung kewajiban untuk mencari nafkah atau membantu orang tua mereka dalam mencari nafkah sehingga memilih untuk menjadi pekerja anak. 
Dorongan yang kuat untuk memenuhi tuntutan kebutuhan hidup membuat pekerja anak rentan mengalami eksploitasi dan dipekerjakan di lingkungan-lingkungan berbahaya (Iryani \& Priyarsono, 2013). Di sisi lain, sebesar 87 persen pekerja anak yang berasal dari rumah tangga tidak miskin juga mengalami eksploitasi. Hal tersebut menunjukkan bahwa seorang anak yang menjadi pekerja anak hingga mengalami eksploitasi tidak hanya didorong semata-mata karena faktor ekonomi dari rumah tangga saja, melainkan adanya motivasi untuk memperoleh pengalaman dan keterampilan tambahan dari pekerjaannya serta meningkatkan kemandirian dari dalam diri anak tersebut (Usman \& Nachrowi, 2004).

Tabel 1: Proporsi Eksploitasi Pekerja Anak di Indonesia Tahun 2018

\begin{tabular}{|c|c|c|c|}
\hline Nama Variabel & Kategori & $\begin{array}{c}\text { Tereksploitasi } \\
\text { (\%) }\end{array}$ & $\begin{array}{c}\text { Tidak } \\
\text { Tereksploitasi } \\
\text { (\%) }\end{array}$ \\
\hline \multirow{2}{*}{$\begin{array}{c}\text { Klasifikasi Wilayah } \\
\text { Tempat Tinggal }\end{array}$} & Perkotaan & 91 & 9 \\
\hline & Pedesaan & 84 & 16 \\
\hline \multirow{2}{*}{ Status Kemiskinan } & Tidak miskin & 87 & 13 \\
\hline & Miskin & 86 & 14 \\
\hline \multirow{2}{*}{$\begin{array}{c}\text { Jenis Kelamin } \\
\text { Anak }\end{array}$} & Perempuan & 83 & 17 \\
\hline & Laki-laki & 89 & 11 \\
\hline \multirow{3}{*}{$\begin{array}{c}\text { Sektor Pekerjaan } \\
\text { Anak }\end{array}$} & Sektor informal & 77 & 23 \\
\hline & $\begin{array}{l}\text { Sektor formal } \\
\text { Bekerja di sektor }\end{array}$ & 98 & 2 \\
\hline & golongan & 88 & 12 \\
\hline \multirow{4}{*}{$\begin{array}{c}\text { Status Pekerjaan } \\
\text { KRT }\end{array}$} & $\begin{array}{l}\text { golongan } \\
\text { pertanian }\end{array}$ & 84 & 16 \\
\hline & Tidak bekerja & 97 & 3 \\
\hline & Perguruan tinggi & 79 & 21 \\
\hline & SMA sederajat & 73 & 27 \\
\hline \multirow{3}{*}{$\begin{array}{c}\text { Status Pendidikan } \\
\text { KRT }\end{array}$} & SMP sederajat & 86 & 14 \\
\hline & SD sederajat & 90 & 10 \\
\hline & $\begin{array}{l}\text { Tidak tamat } \\
\text { sekolah }\end{array}$ & 89 & 11 \\
\hline
\end{tabular}

Sumber: Susenas tahun 2018, diolah

Pekerja anak laki-laki yang mengalami eksploitasi lebih besar proporsinya apabila dibandingkan dengan pekerja anak perempuan yang mengalami eksploitasi. Tercatat bahwa 89 persen di antara pekerja anak berjenis kelamin laki-laki mengalami eksploitasi sedangkan sebesar 83 persen dari pekerja anak dengan jenis kelamin perempuan diketahui mengalami eksploitasi. Lebih besarnya proporsi pekerja anak laki-laki yang mengalami eksploitasi dapat terjadi karena beban ekonomi yang ditanggung oleh anak laki-laki lebih tinggi daripada anak perempuan. Selain itu, 
terdapat tuntutan yang lebih besar bagi anak laki-laki untuk membantu keluarga dalam menopang perekonomian keluarga (Fithriani, 2011).

Kehadiran pekerja anak, baik di sektor formal maupun informal dapat dikatakan sebagai awal timbulnya permasalahan. Proporsi pekerja anak di sektor formal yang tereksploitasi lebih besar apabila dibandingkan dengan proporsi pekerja anak di sektor informal yang mengalami eksploitasi. Sebesar 98 persen pekerja anak pada sektor formal mengalami eksploitasi dan sebesar 77 persen pekerja anak di sektor informal juga mengalami eksploitasi. Lebih besarnya proporsi pekerja anak di sektor formal yang tereksploitasi dapat menandakan bahwa pekerja anak yang bekerja di sektor formal lebih berisiko untuk tereksploitasi. Seorang anak yang memiliki pekerjaan di sektor formal mempunyai jam kerja yang relatif lebih panjang dan memperoleh gaji yang relatif lebih rendah dari pekerja dewasa (Mulandar, 1996).

Sebesar 84 persen pekerja anak dengan KRT yang bekerja di sektor golongan pertanian mengalami eksploitasi. Sementara 88 persen dari pekerja anak yang memiliki KRT bekerja pada sektor golongan nonpertanian mengalami eksploitasi. Selain itu, sebesar 97 persen pekerja anak yang memiliki KRT tidak bekerja mengalami eksploitasi. Proporsi tertinggi dari pekerja anak yang mengalami eksploitasi dimiliki oleh pekerja anak dengan KRT tidak bekerja, hal tersebut menandakan bahwa pekerja anak dengan KRT yang tidak bekerja lebih berisiko untuk mengalami eksploitasi.

Persentase eksploitasi pekerja anak secara umum mengalami penurunan seiring dengan kenaikan tingkat pendidikan dari kepala rumah tangganya. Pekerja anak dengan KRT yang memiliki pendidikan tamat Perguruan Tinggi, sebesar 79 persen di antaranya termasuk pekerja anak yang tereksploitasi. Pekerja anak dengan KRT yang memiliki pendidikan tamat SMA/sederajat, sebesar 73 persen di antaranya termasuk pekerja anak yang tereksploitasi. Pekerja anak dengan KRT yang memiliki pendidikan tamat SMP/sederajat, sebesar 86 persen di antaranya termasuk pekerja anak yang tereksploitasi. Pekerja anak dengan KRT yang memiliki pendidikan tamat SD/sederajat, sebesar 90 persen di antaranya termasuk pekerja anak yang tereksploitasi. Pekerja anak dengan KRT yang tidak tamat SD/sederajat, sebesar 89 persen di antaranya termasuk pekerja anak yang tereksploitasi. Apabila dilihat dari besarnya nilai proporsi pada masing-masing kategori pendidikan KRT, dapat disimpulkan bahwa pekerja anak yang memiliki KRT tamat SD/sederajat akan lebih berisiko untuk mengalami eksploitasi.

\subsection{Analisis Inferensia}

Uji signifikansi parameter dilakukan secara simultan dan parsial. Uji simultan dilakukan untuk mengetahui pengaruh variabel penjelas terhadap variabel respon secara bersama-sama (simultan) di dalam model regresi logistik biner yang dilakukan dengan menggunakan uji Likelihood Ratio.

Tabel 2: Hasil Uji Likelihood Ratio.

\begin{tabular}{ccc}
\hline Statistik G & Derajat Bebas & P-value \\
\hline 930,41 & 10 & $0,00^{*}$ \\
\cline { 2 - 3 }$\alpha=0,05$ & &
\end{tabular}


Tabel 2 menunjukkan hasil uji Likelihood Ratio, yaitu diperoleh nilai G sebesar 930,41 dengan $p$-value sebesar 0,00 yang menunjukkan bahwa nilai $G>\chi^{2}{ }_{10}=18,31$ atau $p$-value $<0,05$ sehingga menghasilkan keputusan tolak $\mathrm{H}_{0}$. Hal ini menunjukkan bahwa berdasarkan sampel yang ada dan dengan tingkat signifikansi 5 persen, minimal terdapat satu variabel penjelas yang berpengaruh secara signifikan terhadap eksploitasi pekerja anak di Indonesia tahun 2018.

Karena keputusan pada uji simultan menunjukkan tolak $\mathrm{H}_{0}$, maka dilanjutkan dengan uji parsial. Uji parsial bertujuan untuk mengetahui variabel penjelas mana yang berpengaruh secara signifikan terhadap variabel respon. Pengujian variabel penjelas secara satu per satu dilakukan melalui uji Wald dan hasilnya ditampilkan pada Tabel 3. Berdasarkan tabel tersebut, dengan sampel yang ada pada tingkat signifikansi 5 persen disimpulkan bahwa variabel klasifikasi wilayah tempat tinggal, jenis kelamin anak, sektor pekerjaan anak, dan pendidikan KRT pada tingkat SMP atau SD atau tidak tamat sekolah signifikan berpengaruh terhadap eksploitasi pekerja anak di Indonesia tahun 2018.

Tabel 3: Hasil Uji Wald

\begin{tabular}{|c|c|c|c|c|c|c|}
\hline $\begin{array}{c}\text { Nama } \\
\text { Variabel }\end{array}$ & Kategori & Simbol & $\widehat{\boldsymbol{\beta}}$ & S.E. & $\begin{array}{c}P- \\
\text { value }\end{array}$ & $\operatorname{Exp}(\widehat{\beta})$ \\
\hline Klasifikasi & $0=$ Perkotaan *) & - & - & - & - & - \\
\hline $\begin{array}{l}\text { Wilayah } \\
\text { Tempat } \\
\text { Tinggal }\end{array}$ & $1=$ Pedesaan & $x_{11}$ & $-0,35$ & 0,12 & $0,00^{*}$ & 0,70 \\
\hline Status & $0=$ Tidak miskin *) & - & - & - & - & - \\
\hline Kemiskinan & $1=$ Miskin & $x_{21}$ & $-0,03$ & 0,10 & 0,80 & 0,97 \\
\hline Jenis & $0=$ Perempuan *) & - & - & - & - & - \\
\hline $\begin{array}{l}\text { Kelamin } \\
\text { Anak }\end{array}$ & 1 = Laki-laki & $x_{31}$ & 0,81 & 0,08 & $0,00^{*}$ & 2,25 \\
\hline Sektor & $0=$ Sektor informal *) & - & - & - & - & - \\
\hline $\begin{array}{l}\text { Pekerjaan } \\
\text { Anak }\end{array}$ & $1=$ Sektor formal & $x_{41}$ & 3,13 & 0,20 & $0,00^{*}$ & 22,92 \\
\hline Status & $\begin{array}{l}0 \text { = Bekerja di sektor } \\
\text { golongan nonpertanian *) }\end{array}$ & - & - & - & - & - \\
\hline $\begin{array}{l}\text { Pekerjaan } \\
\text { KRT }\end{array}$ & $\begin{array}{l}1 \text { = Bekerja di sektor } \\
\text { golongan pertanian }\end{array}$ & $x_{51}$ & 0,06 & 0,10 & 0,54 & 1,06 \\
\hline & 2 = Tidak bekerja & $x_{52}$ & 0,31 & 0,23 & 0,18 & 1,36 \\
\hline & $0=$ Perguruan Tinggi *) & - & - & - & - & - \\
\hline & $1=$ SMA sederajat & $x_{61}$ & 0,07 & 0,25 & 0,79 & 1,07 \\
\hline $\begin{array}{l}\text { Pendidikan } \\
\text { KDT }\end{array}$ & $2=$ SMP sederajat & $x_{62}$ & 0,79 & 0,25 & $0,00^{*}$ & 2,21 \\
\hline & $3=\mathrm{SD}$ sederajat & $x_{63}$ & 1,21 & 0,24 & $0,00^{*}$ & 3,37 \\
\hline & 4 = Tidak tamat sekolah & $x_{64}$ & 1,59 & 0,25 & $0,00^{*}$ & 4,91 \\
\hline Konstanta & - & - & $-0,50$ & 0,24 & $0,04^{*}$ & 0,61 \\
\hline
\end{tabular}

$\left.{ }^{\star}\right)$ : reference category

* : signifikan pada alfa 0,05

Variabel status kemiskinan dan status pekerjaan KRT memiliki nilai $p$-value $>0,05$ sehingga dapat disimpulkan bahwa berdasarkan sampel yang ada dan dengan taraf 
signifikansi 5 persen, variabel status kemiskinan dan status pekerjaan KRT tidak secara signifikan berpengaruh terhadap eksploitasi pekerja anak di Indonesia tahun 2018. Hal tersebut tidak sejalan dengan hasil penelitian Akarro \& Mtweve (2011 dan Iryani \& Priyarsono (2013) yang menyatakan bahwa faktor ekonomi dari setiap individu merupakan salah satu faktor pendorong terjadinya eksploitasi pada pekerja anak. Namun, hasil dari penelitian ini didukung oleh penelitian (Webbink et al., 2013) yang menunjukkan bahwa eksploitasi pekerja anak tidak semata-mata terjadi karena faktor ekonomi yang dimiliki setiap individu. Terdapat pengaruh dari ketersediaan kesempatan kerja bagi pekerja anak di pasar tenaga kerja lokal dan karakteristik ketersediaan fasilitas pendidikan dari wilayah tempat tinggal dalam terjadinya kejadian eksploitasi pekerja anak (Webbink et al., 2013).

Berdasarkan hasil taksiran parameter pada Tabel 3, persamaan regresi logistik biner yang terbentuk yaitu:

$$
\begin{aligned}
\hat{g}(x)= & -0,45^{*}-0,35 x_{11}{ }^{*}-0,03 x_{21}+0,81 x_{31}{ }^{*}+3,13 x_{41}{ }^{*}+0,06 x_{51}+0,31 x_{52}+0,07 x_{61} \\
& +0,79 x_{62}{ }^{*}+1,21 x_{63}{ }^{*}+1,59 x_{64}{ }^{*}
\end{aligned}
$$

Keterangan: * : signifikan pada $\alpha=0,05$

Tabel 4: Uji Hosmer-Lemeshow

\begin{tabular}{ccc}
\hline Chi-square & Derajat Bebas & $\boldsymbol{P}$-value \\
\hline 14,07 & 8 & 0,08 \\
\hline
\end{tabular}

Pengujian ketepatan atau kesesuaian model dilakukan dengan uji HosmerLemeshow yang hasilnya ditampilkan pada Tabel 4. Nilai $p$-value yang dihasilkan sebesar 0,08 sehingga keputusan yang dihasilkan adalah gagal tolak $\mathrm{H}_{0}$ yang menunjukkan bahwa berdasarkan sampel yang ada dengan tingkat signifikansi 5 persen, model yang terbentuk sudah memiliki hasil yang sesuai dengan data observasi (model fit).

Selanjutnya dilakukan interpretasi nilai rasio kecenderungan yang diperoleh pada Tabel 3. Klasifikasi wilayah tempat tinggal mempunyai pengaruh yang signifikan terhadap eksploitasi pekerja anak. Nilai rasio kecenderungan sebesar 0,70 menunjukkan bahwa seorang pekerja anak yang bertempat tinggal di daerah pedesaan memiliki kecenderungan yang lebih kecil untuk tereksploitasi dibandingkan pekerja anak yang tinggal didaerah perkotaan. Pekerja anak yang bertempat tinggal di perkotaan memiliki kecenderungan 1/70 atau 1,43 kali untuk tereksploitasi dibandingkan pekerja anak yang bertempat tinggal di pedesaan. Salah satu penyebabnya adalah rata-rata pendapatan atau penghasilan dari pekerja anak yang bekerja di sektor informal lebih baik dibandingkan dengan pekerja anak yang bekerja di sektor formal dan pekerjaan pada sektor formal lebih mudah dijumpai di perkotaan (Usman \& Nachrowi, 2004).

Jenis kelamin anak signifikan berpengaruh terhadap eksploitasi pekerja anak. Pekerja anak yang berjenis kelamin laki-laki cenderung untuk mengalami eksploitasi dibandingkan dengan pekerja anak yang berjenis kelamin perempuan. Nilai rasio kecenderungan sebesar 2,25 menunjukkan bahwa pekerja anak yang berjenis kelamin laki-laki memiliki kecenderungan 2,25 kali untuk mengalami eksploitasi dibandingkan pekerja anak yang berjenis kelamin perempuan dengan asumsi variabel lain bernilai 
konstan. Hal tersebut sejalan dengan hasil penelitian yang dilakukan Fithriani (2011) dan Iryani \& Priyarsono (2013) yang menyatakan bahwa beban ekonomi yang ditanggung anak laki-laki lebih besar daripada anak perempuan sehingga menimbulkan tuntutan yang besar bagi anak laki-laki untuk menopang perekonomian keluarga. Kondisi tersebut membuat pekerja anak laki-laki semakin rentan mengalami eksploitasi dan dipekerjakan di lingkungan berbahaya.

Sektor pekerjaan anak berpengaruh secara signifikan terhadap eksploitasi pekerja anak. Pekerja anak yang bekerja pada sektor formal cenderung untuk lebih tereksploitasi dibandingkan pekerja anak yang bekerja pada sektor informal. Nilai rasio kecenderungan sebesar 22,92 menunjukkan bahwa pekerja anak yang bekerja di sektor formal memiliki kecenderungan 22,92 kali untuk mengalami eksploitasi dibandingkan pekerja anak yang bekerja di sektor informal dengan asumsi variabel lain bernilai konstan. Berdasarkan hasil analisis deskriptif, diketahui bahwa sebesar 53 persen dari pekerja anak yang tereksploitasi merupakan pekerja anak yang bekerja di sektor formal. Salah satu kriteria pekerja anak yang tercakup kedalam kategori bekerja di sektor formal adalah pekerja anak yang memiliki status sebagai buruh, karyawan, atau pegawai, dan sebesar 20,59 persen dari pekerja anak ini tereksploitasi. Seorang buruh, karyawan, atau pegawai memiliki ikatan jam kerja dalam pekerjaannya yang lamanya sesuai dengan aturan yang ditetapkan oleh orang atau badan yang mempekerjakannya. Fakta tersebut didukung oleh hasil penelitian yang menyatakan bahwa anak yang bekerja di sektor formal akan bekerja dengan jam kerja relatif panjang dan memperoleh gaji yang relatif lebih rendah dari pekerja dewasa sehingga rawan mengalami eksploitasi dan gangguan penyakit (Mulandar, 1996).

Pada variabel pendidikan KRT, hasil uji parsial menunjukkan bahwa pendidikan KRT berpengaruh signifikan terhadap status eksploitasi pekerja anak. Namun, seorang pekerja anak yang memiliki KRT berpendidikan SMA sederajat tidak secara signifikan memengaruhi status eksploitasi pekerja anak. Seorang pekerja anak yang memiliki KRT berpendidikan SMP sederajat memiliki kecenderungan 2,21 kali untuk tereksploitasi dibandingkan pekerja anak yang memiliki KRT berpendidikan Perguruan Tinggi dengan asumsi variabel lain konstan. Pekerja anak yang memiliki KRT berpendidikan SD sederajat memiliki kecenderungan 3,37 kali untuk mengalami eksploitasi dibandingkan pekerja anak yang mempunyai KRT berpendidikan Perguruan Tinggi dengan asumsi variabel lain konstan. Seorang pekerja anak yang mempunyai KRT tidak tamat sekolah memiliki kecenderungan 4,91 kali untuk mengalami eksploitasi dibandingkan pekerja anak yang mempunyai KRT tamat Perguruan Tinggi dengan asumsi variabel lain konstan. Oleh karena itu, dapat ditarik sebuah kesimpulan bahwa besarnya nilai kecenderungan seorang pekerja anak untuk tereksploitasi akan semakin meningkat seiring dengan semakin rendahnya pendidikan yang dimiliki KRT. 


\section{Simpulan}

Sebagian besar pekerja anak di Indonesia tahun 2018 mengalami eksploitasi. Provinsi dengan persentase eksploitasi pekerja anak tertinggi adalah DKI Jakarta, Banten, dan Jawa Tengah. Klasifikasi wilayah tempat tinggal, jenis kelamin anak, sektor pekerjaan anak, dan pendidikan KRT signifikan berpengaruh terhadap eksploitasi pekerja anak. Pekerja anak yang bertempat tinggal di perkotaan, berjenis kelamin laki-laki, bekerja di sektor formal, dan memiliki KRT dengan tingkat pendidikan SMP sederajat atau SD sederajat atau tidak tamat sekolah memiliki kecenderungan lebih besar untuk mengalami eksploitasi.

\section{Daftar Pustaka}

Agresti, A. (2007). Introduction to Categorical Data Analysis (2nd ed.). New Jersey (US): John Wiley \& Sons, Inc.

Akarro, R. R. J., \& Mtweve, N. A. (2011). Poverty and Its Association with Child Labor in Njombe District in Tanzania: The Case of Igima Ward. 3(3): 199-206.

[BPS] Badan Pusat Statistik. (2010). Pekerja Anak di Indonesia 2009. Retrieved June 18, 2020, from https://www.bps.go.id/publication/2010/01/26/ 16e071626b6d67e4fd413019/pekerja-anak-di-indonesia-2009.html

Fithriani, R. (2011). Pekerja Anak, Kemiskinan, dan Nilai Ekonomi Anak, Studi Kasus Provinsi Lampung Tahun 2011.

Hosmer, D. W., Lemeshow, S., \& Sturdivant, R. X. (2013). Applied Logistic Regression (Third). Hoboken (NJ): Wiley.

[ILO] International Labour Office. (2004). Indonesia, Working Out of Poverty. Jakarta (ID): International Labour Organization.

Iryani, B. S., \& Priyarsono, D. S. (2013). Eksploitasi terhadap Anak yang Bekerja di Indonesia. Jurnal Ekonomi dan Pembangunan Indonesia, 13(2): 177-195. https://doi.org/10.21002/jepi.v13i2.226

Joni, M., \& Tanamas, Z. Z. (1999). Aspek hukum perlindungan anak dalam perspektif Konvensi Hak Anak (Cet. 1). Bandung (ID): Citra Aditya Bakti.

[KEMNAKER] Kementerian Ketenagakerjaan Republik Indonesia. (2014). Peta jalan menuju Indonesia bebas pekerja anak 2022. Retrieved June 18, 2020, from http://www.ilo.org/jakarta/whatwedo/publications/WCMS_377169/lang-en/index.htm

[KPAI] Komisi Perlindungan Anak Indonesia. (2016). Rincian Data Kasus Trafficking dan Eksploitasi - 2015 | Bank Data Perlindungan Anak. Retrieved June 18, 2020, from https://bankdata.kpai.go.id/tabulasi-data/data-kasus-per-bulan/rincian-datakasus-trafficking-dan-eksploitasi-2015 
Mulandar, S. (1996). Dehumanisasi anak marjinal: berbagai pengalaman pemberdayaan. Retrieved from http://catalog.hathitrust.org/api/volumes/ oclc/35808827.html

Silitonga, M. (2009). Faktor-faktor yang mempengaruhi terjadinya eksploitasi pekerja anak di Indonesia: (analisis data susenas tahun 2006). Jakarta (ID): Universitas Indonesia.

Sulastri, D. (2016). Faktor-Faktor Yang Menyebabkan Eksploitasi Pekerja Anak Pada Tambang Emas Tradisional Desa Kelian Dalam Di Kecamatan Tering. 4(2): 252265.

Usman, H., \& Nachrowi, N. D. (2004). Pekerja anak di Indonesia: kondisi, determinan, dan eksploitasi: kajian kuantitatif. Jakarta (ID): Gramedia Widiasara Indonesia.

Webbink, E., Smits, J., \& de Jong, E. (2013). Household and Context Determinants of Child Labor in 221 Districts of 18 Developing Countries. Social Indicators Research, 110(2): 819-836. https://doi.org/10.1007/s11205-011-9960-0 